\title{
Selection of substrate material for hybrid microwave integrated circuits (HMICs)
}

\section{Navneet Gupta,}

\author{
Abhinav Mishra \\ Department of Electrical \\ and Electronics Engineering, \\ Birla Institute of Technology \\ and Science, \\ Pilani-333 031, \\ Rajasthan, India \\ E-mailngupta@pilani.bits-pilani.ac.in
}

This paper presents systematic approach of material selection for substrate material in hybrid microwave integrated circuits (HMICs). The performance of HMICs starts deteriorating at microwave frequencies because the circuit dimensions become comparable to the wavelength. So, it is important to design HMICs in such a way that its performance remains unaffected even at high frequencies. One way to fulfil this requirement is to fabricate a proper device. For this, substrate material in HMICs plays an important role. But there are different types of materials available which can be used as substrate material of HMICs. The commonly reported materials are: Silicon ( $\mathrm{Si}$ ), Gallium Arsenide (GaAs), Indium Phosphide (InP), Alumina $\left(\mathrm{Al}_{2} \mathrm{O}_{3}\right)$, Beryllia, Fused Silica, Sapphire, Woven PTFF/ Glass, PTFE/Glass, Polyolefin, and Ferrite/Granite. As each material is having its own advantages and limitations; therefore, it is important to choose the best possible material out of all possible materials. For this purpose two decision making techniques are used. Firstly, Ashby's approach as the Multi-Objective Decision Making (MODM) technique is used, and then the Technique for Order Preference by Similarity to Ideal Solution (TOPSIS) as the Multiple Attribute Decision Making (MADM) technique is used. Ashby's approach provides effective material selection technique to select the best material based on their material and performance indices for better device performance. While TOPSIS approach is a decision making approach which is basically used to determine the best alternative which should have the shortest Euclidean distance $\left(S^{*}\right)$ from the ideal solution $\left(\mathrm{A}^{*}\right)$ and the largest Euclidean distance (S-) from the negative ideal solution (A-). For MICs, the material indices considered and evaluated are surface roughness, relative dielectric constant, loss tangent, thermal conductivity, and dielectric strength. It is observed that Sapphire followed by high-purity Alumina (99.5 percent pure or better) are good candidates for substrate material in hybrid MICs. The surface roughness of Sapphire is better than that of Alumina, though the dielectric strength of both these materials is the same. A comparison between two different methods for material selection shows consistency between the two methods of material selection. Both methodologies show that Sapphire is the most suitable substrate material for hybrid MICs.

Key words: material selection, microwave integrated circuits (MICs), TOPSIS, Ashby's approach, MADM, MODM 


\section{INTRODUCTION}

Microwave integrated circuits (MICs) are integrated circuits designed at frequencies of approximately $1 \mathrm{GHz}$ or more. These MICs provide a significant opportunity to integrate and miniaturize the microwave subsystems and systems compared to those which are based on waveguide components. There are two distinct types of MICs: hybrid MICs and monolithic MICs. A hybrid MIC contains one layer of metallization for conductors and transmission lines, with discrete components (resistors, capacitors, transistors, diodes, etc.) bound to the substrate. It provides a very flexible and cost-effective means for circuit implementation. On the other hand, MMICs are a more recent development, where the active and passive circuit elements are grown on the substrate. The substrate is a semiconductor material, and several layers of metal, dielectric and resistive films are used. However, HMICs have several advantages over MMICs such as small size, light weight, good performance, high reliability, standard packages and easy to be mounted [1]. It can be widely used in T/R modules, up/down converters and can also be used directly in hybrid analog-digital integrated digital components.

At microwave frequencies ( $1 \mathrm{GHz}$ or more), the circuit dimensions become comparable to an order of the wavelength which influences the performance of MICs [2-3]. This further reflects on the choice of the materials that are used to fabricate the MICs. Therefore, as compared to the low frequency circuits, the quality requirements are more challenging for the materials used for the fabrication of MICs. Moreover, in fabrication of HMICs, substrate plays an important role and with the development of fabrication techniques, the number of materials used as substrate for HMICs has been increased [4-5]. This provides a new challenge for optimum selection of materials for HMICs, and hence a systematic approach for material selection is needed.

Material selection is a critical step in the design of any engineering product because the overall goal of a design is to achieve specific performance characteristics of the device. This goal can be achieved by using an effective, well established and widely accepted decision making approaches: MODM and MADM [6-9]. Ashby's approach is based on MODM which uses material selection charts plotted between competing material parameters based on various performance indices. TOPSIS is based on MADM that concentrates on problems with discrete decision spaces, and alternatives are defined explicitly by a finite list of attributes. Both these approaches are used for the selection of substrate material for HMICs. The key performance indices are identified, and these competing factors are compared for various materials. The novelty of this work lies in the fact that the well established material selection approaches are used to select the proper substrate material, which was not reported so far.

This paper is organized as follows: Section 2 explains the substrate materials used for HMICs and material selection techniques, Section 3 presents the description about the performance and material indices, Section 4 explains the results obtained using both the methodologies for material selection, and finally Section 5 discusses the conclusion of the study.

\section{MATERIALS AND TECHNIQUES}

For MICs various material parameters such as surface roughness, relative dielectric constant, loss tangent, thermal conductivity and dielectric strength are important and must be evaluated [5]. For HMICs, Silicon (Si), Gallium Arsenide (GaAs), Indium Phosphide (InP), Alumina $\left(\mathrm{Al}_{2} \mathrm{O}_{3}\right)$, Beryllia, Fused Silica, Sapphire, Woven PTFF/Glass, PTFE/Glass, Polyolefin, and Ferrite/Granite are commonly used for substrates [5]. The ideal substrate materials for microwave microcircuits should possess certain material characteristics which are: high dielectric constant, low loss tangent, high resistivity and dielectric strength and high thermal conductivity. These properties for all possible candidate materials are given in Table 1 . Besides material characteristics, the performance of the device also depends on chemical and physical properties of the substrate materials such as high purity, constant thickness, and high surface smoothness. In material selection analysis, Ferrite and Granite have been discarded from the possible group of substrate materials because they have unacceptably low thermal conductivity and dielectric strength and skew the selection chart hindering 
Table 1. Various properties of different possible materials for substrate in HMICs

\begin{tabular}{|c|c|c|c|c|c|}
\hline $\begin{array}{l}\text { Substrate } \\
\text { material }\end{array}$ & $\begin{array}{c}\text { Surface } \\
\text { roughness } \\
(\mu \mathrm{m})\end{array}$ & $\begin{array}{c}\text { Relative dielectric } \\
\text { constant }\left(\varepsilon_{\mathrm{r}}\right) \\
\left(\text { at } 25^{\circ} \mathrm{C}\right)\end{array}$ & $\begin{array}{c}\text { Loss tangent } \\
\text { (measured at } \\
10 \mathrm{GHz} \text { ) }\end{array}$ & $\begin{array}{l}\text { Thermal consuctivity } \\
\left(\mathrm{W} / \mathrm{cm}^{\circ} \mathrm{C}\right)\end{array}$ & $\begin{array}{l}\text { Dielectric strenght } \\
\left(\mathrm{kV} / \mathrm{cm}\left(\times 10^{3}\right)\right.\end{array}$ \\
\hline \multicolumn{6}{|c|}{ Semiconductor } \\
\hline $\mathrm{Si}$ & 1 & 11.85 & 95 & 0.9 & 0.3 \\
\hline GaAs & 1 & 12.9 & 16 & 0.3 & 0.35 \\
\hline $\ln P$ & 0.9 & 13.25 & 21 & 0.68 & 0.32 \\
\hline \multicolumn{6}{|c|}{ Ceramic } \\
\hline Alumina & 5 & 14.75 & 0.8 & 0.8 & 4 \\
\hline Beryllia & 26 & 6.7 & 3 & 2.5 & 0.2 \\
\hline Fused Silica & 1 & 3.8 & 0.9 & 0.013 & 0.35 \\
\hline Sapphire & 1 & 15.5 & 0.7 & 0.9 & 4 \\
\hline \multicolumn{6}{|c|}{ Polymeric } \\
\hline Woven PTFF/Glass & 1.5 & 2.2 & 9 & 0.0026 & 0.4 \\
\hline PTFE/Glass (Grade II) & 1.75 & 2.1 & 4.5 & 0.003 & 0.42 \\
\hline PTFE/Glass (Grade I) & 1.8 & 10.5 & 15 & 0.004 & 0.45 \\
\hline Polyolefin & 2 & 2.3 & 1 & 0.001 & 0.3 \\
\hline Ferrite/Granite & 2 & 1316 & 2 & 0.03 & 0.45 \\
\hline
\end{tabular}

its proper interpretation to select the most appropriate material for HMICs.

Ashby's material selection technique is instrumental in identifying the most appropriate material for optimum performance depending upon the mechanical, electrical and thermal attributes of the material. Ashby's material selection approach involves five steps, as illustrated in Fig. 1. In the first step, the design requirements are translated into the objectives that are necessary to optimize the device performance and the constraints that material must meet. In the second step, the wide choices of possible materials are confined, first by applying the constraints which screen out the materials that do not fulfil the design requirement and then by considering the material indices. In the third step, ranking is provided to the material based on their ability to fulfil the objective and to provide the better performance. In the next step, the supporting information for the shortlist material termed as a prime candidate is explored and the final result of the best suitable material is compared with the supporting experimental data. Material selection through performance indices is carried out by plotting one material property on each axis of the material selection chart $[8,10]$. The design of a component under consideration is specified by three parameters: functional requirements, geometrical properties, and material properties. The performance of an element is described by:

$$
P=f(F, G, M) .
$$

Here, $P$ describes the performance of the element, and $f$ describes the functions of the functional requirement $(F)$, geometrical properties $(G)$, and material properties $(M)$, respectively.

$$
P=f_{1}(F) f_{2}(G) f_{3}(M) .
$$

Here, element performance is described by individual functions of $F, G$, and $M$. Hence, the optimum subset of material can be identified by a single functional requirement. For $F$ and $G$, the performance can be optimized by optimizing the appropriate material indices. This optimization is conventionally performed using graphs with axes corresponding to different material indices or material properties.

In TOPSIS method, two artificial alternatives are hypothesized. One, which has the best attribute values, is taken as an ideal alternative, while the other one, which has the worst attribute values, 
All possible materials

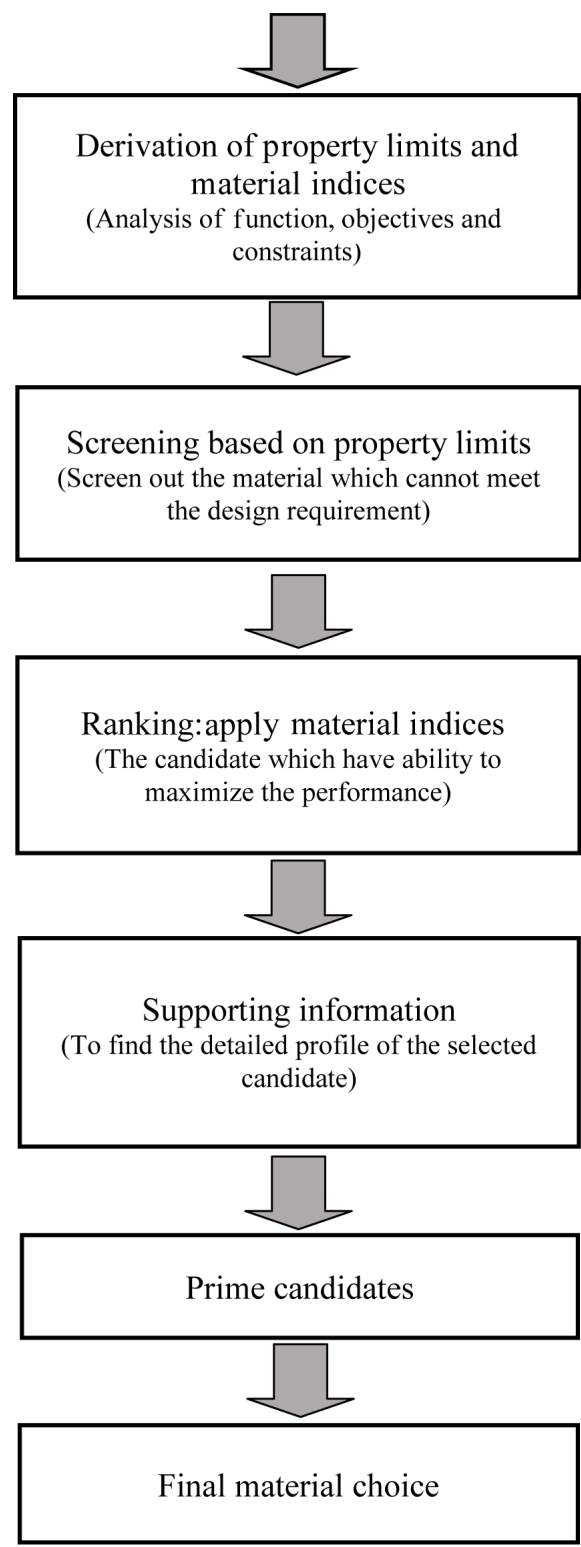

Fig. 1. Material selection chart for Ashby's methodology

is considered a negative ideal alternative. TOPSIS selects the alternative that is the closest to the ideal solution and farthest from the negative ideal solution. The steps for using the TOPSIS approach are given in Gupta [9].

\section{PERFORMANCE INDICES}

\section{Dielectric loss}

The dielectric loss in microstrip or suspended microstrip transmission lines is an important parameter in the design of HMICs. This loss can be computed if the loss tangent of the dielectric substrate and the electric field distribution inside the substrate are known.

The effective dielectric constant of a microstrip lines partially filled with dielectric material is defined by [11]:

$$
\varepsilon_{e f f}=\left(\frac{\lambda_{0}}{\lambda}\right)^{2}
$$

where $\lambda_{0}$ is the vacuum wavelength and $\lambda$ is the wavelength of the propagating mode on the microstrip. So, the first material index related to the dielectric loss is:

$$
M I_{1}=\varepsilon_{\text {eff. }}
$$

The filling factor $q$ of the microstrip is defined by:

$$
q=\frac{U_{1}}{U}
$$

where $U_{1}$ is the electric field energy stored in the dielectric and $U$ is the total electric field energy of the microstrip.

If the partial derivative of the total electric field energy $U$ is computed with respect to the relative dielectric constant $\varepsilon_{1}$ of the substrate, the following result is obtained:

$$
\frac{\partial U}{\partial \varepsilon_{1}}=\frac{U_{1}}{\varepsilon_{1}}
$$

The filling factor $q$ is now given by:

$$
q=\frac{\varepsilon_{1}}{\varepsilon_{e f f}} \frac{\partial \varepsilon_{e f f}}{\partial \varepsilon_{1}} \tan (\delta)
$$

The effective loss tangent of the microstrip is:

$$
(\tan (\delta))_{e f f}=\frac{\varepsilon_{1}}{\varepsilon_{e f f}} \frac{\partial \varepsilon_{e f f}}{\partial \varepsilon_{1}} \tan (\delta)
$$

with $\tan (\delta)$ being the loss tangent and $\delta$ being the loss angle of the dielectric substrate.

So, the second material index related to dielectric loss is:

$$
M I_{2}=\tan (\delta) .
$$


The unloaded dielectric quality factor $Q_{D}$ of the microstrip is:

$$
Q_{D}=\frac{1}{(\tan (\delta))_{\text {eff }}}=\frac{1}{q \cdot \tan (\delta)} .
$$

The dielectric attenuation in $\mathrm{dB}$ per unit length is given by:

$$
\alpha_{D}=\frac{20 \pi}{\ln (10)} \frac{q \cdot \tan (\delta)}{\lambda}=27.3 \frac{(\tan (\delta))_{e f f}}{\lambda}
$$

with $\lambda$ being the microstrip wavelength $\lambda=\frac{\lambda_{0}}{\sqrt{\varepsilon_{e f f}}}$.

So, the third material index related to dielectric loss is:

$$
M I_{3}=a_{D}
$$

Therefore, the first performance index related to dielectric loss is:

$$
P I_{1}=f\left(\varepsilon_{e f f} \delta, \alpha_{D}\right) .
$$

\section{Electrical loss}

Electrical loss is another important performance index related to loss in MICs, which can be reduced significantly by choosing suitable substrate material having good conductivity. Power dissipated in the substrate is given by [12]:

$$
P_{\text {loss }}=I^{2} \cdot R,
$$

where $I$ is the average current in the substrate and $R$ is the effective substrate resistance given by [11]:

$$
R=\frac{\beta \rho L}{4 t w},
$$

where $\beta$ is a constant and related to the current crowding in the substrate and $\rho$ is the electrical resistivity of the substrate. From (12) and (13) we can conclude that power loss in substrate is directly proportional to the electrical resistivity of the substrate material. Therefore, the fourth material index related to the power loss is:

$$
M I_{4}=\rho .
$$

Therefore, the second performance index related to electrical loss in MICs is:

$$
P I_{2}=\mathrm{f}(\rho) \text {. }
$$

\section{Thermal residual stress}

For high frequencies, the substrate material in HMICs experiences the temperature change due to self-heating which causes further change in thermal residual stress which is given by [11].

$$
\Delta \sigma=E \Delta \alpha P_{\text {loss }} R_{T H} \text {, }
$$

where $\Delta \alpha$ is the difference in thermal expansion coefficient between the substrate and conductor, $P_{\text {loss }}$ is the loss in MIC, and $R_{T H}$ is the thermal resistance which is given by [11]:

$$
R_{T H}=\frac{\varepsilon L}{4 K t w} .
$$

where $K$ is the thermal conductivity and $\varepsilon$ is the non-uniform temperature distribution. The product of electrical and thermal resistances of the substrate material $\left(R \cdot R_{T H}\right)$ produces the self-heating in the substrate material of hybrid MICs.

From the above two equations we therefore conclude that the fifth material index is:

$$
M I_{5}=R_{T H} \cdot R=\frac{1}{K} \cdot \rho .
$$

Therefore, the third performance index related to the thermal residual stress in the substrate of hybrid MICs is:

$$
P I_{3}=f\left(\frac{1}{K} \cdot \rho\right) \text {. }
$$

\section{RESULTS AND DISCUSSION}

Out of the five parameters tabulated in Table 1, relative dielectric constant, loss tangent, and thermal conductivity are of primary importance in determining the appropriate substrate material for hybrid MICs [9]. Hence, Ashby's charts will be plotted for these three parameters only, and remaining parameters are used to make final decision between top two outcome materials.

\section{Asbhy's approach}

The optimal performance of hybrid MIC material varies with different performance indices. The material selection graphs are used to select the optimal candidate for HMICs material and also used to identify the trade-offs between 
the conflicting material indices. The desirable properties of the substrate materials used in hybrid MICs are: high dielectric constant, high thermal conductivity, and low loss tangent.

Figure 2 shows a plot of relative dielectric constant $\left(\right.$ at $25^{\circ} \mathrm{C}$ ) versus loss tangent (measured at $10 \mathrm{GHz}$ ) for the materials under consideration. It is known that high dielectric constant with low loss tangent is the desired. It is observed from the graph that Sapphire is the best candidate that fulfil this requirement followed by high-purity Alumina. Figure 3 depicts the variation of thermal conductivity with loss tangent (measured at $10 \mathrm{GHz}$ ) for the materials under consideration. It is observed that Sapphire followed by high-purity Alumina possess the highest thermal conductivity and lowest loss tangent. Figure 4 shows the variation of relative dielectric constant (at $25^{\circ} \mathrm{C}$ ) with thermal conductivity for the materials under consideration. It is observed that Sapphire and high-purity Alumina have the highest thermal conductivity and highest relative dielectric constant. Thus, Sapphire followed by high-purity Alumina (99.5 percent pure or better) are good candidates for substrate material in hybrid MICs. Also according to Table 1, it appears that surface roughness of

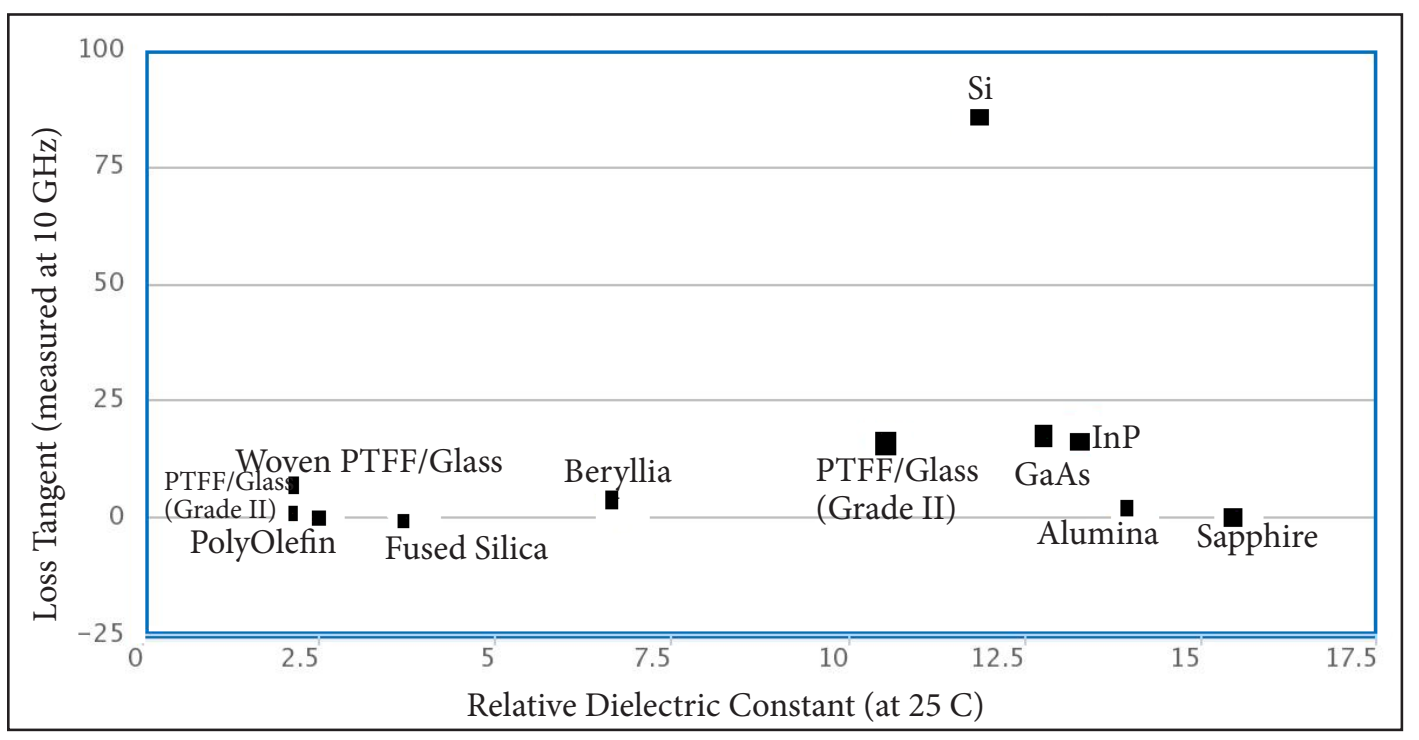

Fig. 2. Relative dielectric constant versus loss tangent for considered materials

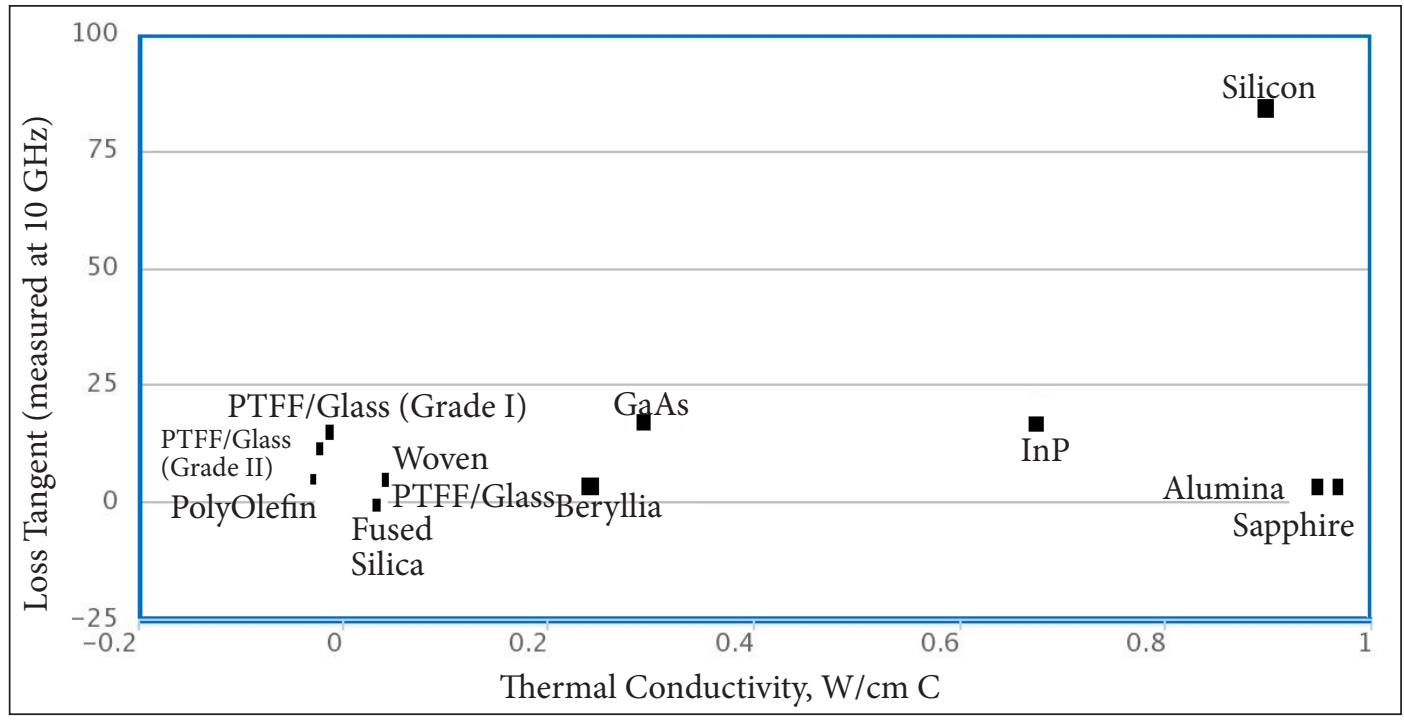

Fig. 3. Thermal conductivity versus loss tangent for considered materials 


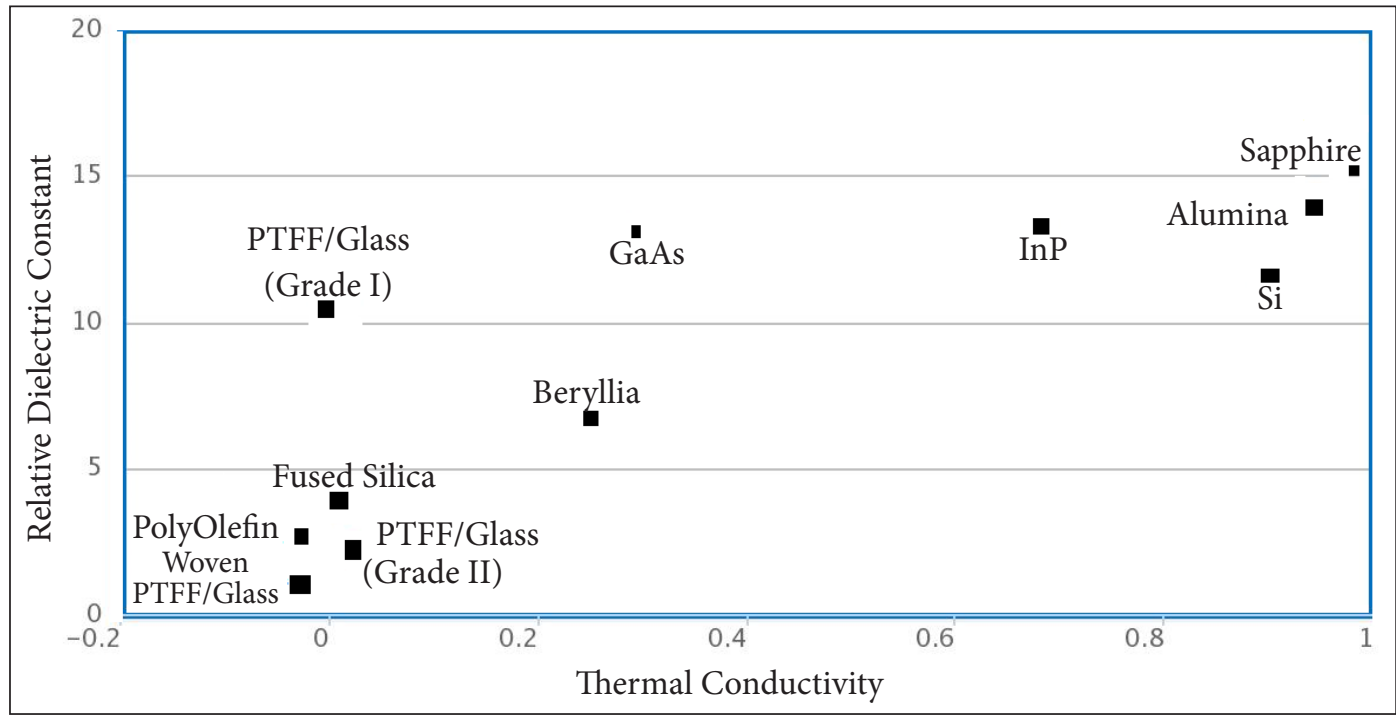

Fig. 4. Relative dielectric constant versus thermal conductivity for considered materials

Sapphire is better than Alumina, though the dielectric strength of both these materials are the same.

Therefore, Sapphire is the most appropriate choice of substrate material for HMICs. This fact is verified in the following sections via the TOPSIS approach.

\section{TOPSIS approach}

In order to verify the outcome of the result from the Ashby's approach, MADM approach - TOPSIS is used. The various relevant properties of different possible materials have already been tabulated in Table 1.

Step I:

The normalized decision matrix based on the various properties is:

\begin{tabular}{|lllll}
\hline 0.0373 & 0.3534 & 0.9472 & 0.2989 & 0.0521 \\
\hline 0.0373 & 0.3847 & 0.1595 & 0.0996 & 0.0608 \\
\hline 0.0336 & 0.3952 & 0.2093 & 0.2259 & 0.0556 \\
\hline 0.1866 & 0.4399 & 0.0079 & 0.2660 & 0.6952 \\
\hline 0.9701 & 0.1998 & 0.0299 & 0.8305 & 0.0348 \\
\hline 0.0373 & 0.1133 & 0.0090 & 0.0043 & 0.0608 \\
\hline 0.0373 & 0.4623 & 0.0070 & 0.2989 & 0.6951 \\
\hline 0.0559 & 0.0656 & 0.0900 & 0.0009 & 0.6951 \\
\hline 0.0653 & 0.0626 & 0.0449 & 0.0010 & 0.0730 \\
\hline 0.0672 & 0.3131 & 0.1496 & 0.0013 & 0.0782 \\
\hline 0.0746 & 0.0686 & 0.0099 & 0.0003 & 0.0521 \\
\hline
\end{tabular}

Step II:

The second step in the TOPSIS method is to assign weights to the various properties on which the various materials under consideration are being compared, and thus construct the weight matrix. Relative dielectric constant and loss tangent are the most important parameters, followed by thermal conductivity, dielectric strength, and surface roughness [9]. Hence, the highest weight is given to the parameter which is the most essential:

$$
W=\left[\begin{array}{lllll}
1 & 5 & 4 & 3 & 2
\end{array}\right] .
$$

Step III:

With the normalized decision matrix and weight matrix, the weighted normalized matrix can be generated as follows:

\begin{tabular}{|c|c|c|c|c|c|}
\hline \multirow{11}{*}{$V=V R$} & 0.0373 & 1.7670 & 3.7888 & 0.8967 & 0.1042 \\
\hline & 0.0373 & 1.9235 & 0.6380 & 0.2988 & 0.1216 \\
\hline & 0.336 & 1.9760 & 0.8372 & 0.6777 & 0.1112 \\
\hline & 0.1866 & 2.1995 & 0.0316 & 0.7980 & 1.3904 \\
\hline & 0.9701 & 0.9990 & 0.1196 & 2.4915 & 0.0696 \\
\hline & 0.0373 & 0.5665 & 0.0360 & 0.0129 & 0.1216 \\
\hline & 0.0373 & 2.3115 & 0.0280 & 0.8967 & 1.3902 \\
\hline & 0.0559 & 0.3280 & 0.3600 & 0.0027 & 1.3902 \\
\hline & 0.0653 & 0.3130 & 0.1796 & 0.0030 & 0.1460 \\
\hline & 0.0672 & 1.5655 & 0.5984 & 0.0039 & 0.1564 \\
\hline & 0.0746 & 0.3430 & 0.0396 & 0.0009 & 0.1042 \\
\hline
\end{tabular}


Step IV:

From the above weighted normalized matrix, the value of separation variables was found out to be:

\begin{tabular}{cc}
\hline$S^{*}$ Values & $S^{-}$Values \\
\hline$S_{1}{ }^{*}=0.4421$ & $S_{1}{ }^{-}=0.2815$ \\
\hline$S_{2}{ }^{*}=0.1945$ & $S_{2}{ }^{-}=0.1387$ \\
\hline$S_{3}{ }^{*}=0.2526$ & $S_{3}{ }^{-}=0.2308$ \\
\hline$S_{4}{ }^{*}=1.1125$ & $S_{4}{ }^{-}=1.6625$ \\
\hline$S_{5}{ }^{*}=1.0376$ & $S_{5}{ }^{-}=1.0258$ \\
\hline$S_{6}{ }^{*}=0.2851$ & $S_{6}{ }^{-}=0.3268$ \\
\hline$S_{7}{ }^{*}=1.0005$ & $S_{7}{ }^{-}=1.9357$ \\
\hline$S_{8}{ }^{*}=0.1982$ & $S_{8}{ }^{-}=0.1349$ \\
\hline$S_{9}{ }^{*}=0.2196$ & $S_{9}{ }^{-}=0.1564$ \\
\hline$S_{10}{ }^{*}=0.2087$ & $S_{10}{ }^{-}=0.0376$ \\
\hline$S_{11}{ }^{*}=0.0487$ & $S_{11}{ }^{-}=0.2119$ \\
\hline
\end{tabular}

The ideal solutions are given in Table 2. The ranks are assigned according to the ' $C$ ' values. The material with the highest ' $C$ ' value was given the best rank. Table 2 shows that Sapphire possesses the highest ' $C$ ' value followed by Alumina thus; Sapphire is the most appropriate choice as substrate material for HMICs. The proposed outcome of this study is compared with the findings

Table 2. Solution of study based on TOPSIS method

\begin{tabular}{ccccc}
\hline Material & Solutions & $\begin{array}{c}\text { Value of } \\
\text { corresponding 'C }\end{array}$ & Rank \\
\hline $\mathrm{Si}$ & $C_{5}$ & 0.3890 & 5 \\
\hline GaAs & $C_{4}$ & 0.4163 & 4 \\
\hline InP & $C_{3}$ & 0.4775 & 3 \\
\hline Alumina & $C_{2}$ & 0.5991 & 2 \\
\hline Beryllia & $C_{7}$ & 0.2956 & 7 \\
\hline Fused Silica & $C_{8}$ & 0.2429 & 8 \\
\hline Sapphire & $C_{1}$ & 0.6593 & 1 \\
\hline Woven PTFF/Glass & $C_{10}$ & 0.1981 & 10 \\
\hline PTFF/Glass (Grade II) & $C_{11}$ & 0.0972 & 11 \\
\hline PTFF/Glass (Grade I) & $C_{6}$ & 0.3321 & 6 \\
\hline Polyolefin & $C_{9}$ & 0.2015 & 9 \\
\hline
\end{tabular}

of Keister [5]. The close match between the two studies validates the proposed methodology.

\section{CONCLUSIONS}

Two material selection methodologies, Ashby's approach and TOPSIS, were used for selecting the best material for substrate in HMICs. The material parameters which were considered for selection were surface roughness, relative dielectric constant, loss tangent, thermal conductivity, and dielectric strength. The possible materials that were considered were Silicon (Si), Gallium Arsenide (GaAs), Indium Phosphide (InP), Alumina $\left(\mathrm{Al}_{2} \mathrm{O}_{3}\right)$, Beryllia, Fused Silica, Sapphire, Woven PTFF/Glass, PTFE/Glass, Polyolefin, and Ferrite/Granite. Both the methodologies show that Sapphire followed by high-purity Alumina (99.5 percent pure or better) are good candidates for substrate material in hybrid MICs. The surface roughness of Sapphire is better than that of Alumina, though the dielectric strength of both these materials is same. A comparison between two different methods for material selection shows consistency between the two methods of material selection. So, this paper provides a good solution to a design engineer to fabricate the HMICs which can be operated even at microwave frequencies.

Received 5 April 2016 Accepted 15 May 2016

\section{References}

1. Pozar D. M. Microwave Engineering. 4th ed. USA: John Wiley and Sons, Inc., 2012.

2. Bhat B., Koul S. K. Stripline-like Transmission Lines for Microwave Integrated Circuits. New Delhi: Wiley Eastern Ltd, 1989.

3. Nie A. G., Goedbloed G. Reliability and Degradation of Microwave Integrated Circuits. New York: John Wiley \& Sons Ltd, 1981. P. 363-439.

4. Boles T. HMIC the ultimate SOI microwave integrated circuit technology. IEEE Int. Conf. on Microwaves, Comm., Antennas and Electronics Systems (COMCAS), November 2011. P. 1-6.

5. Das A., Das S. K. Microwave Engineering. 2nd ed. New Delhi: McGraw-Hill Publication, 2009. Ch 4. P. 95. 
6. Chauhan A., Vaish R. A comparative study on material selection for microelectromechanical systems. Mater Des. 2012. Vol. 41. P. 177-81.

7. Yazdani M., Payam A. F. A comparative study on material selection of microelectromechanical systems electrostatic actuators using Ashby, VIKOR and TOPSIS. Mater Des. 2015. Vol. 65. P. 328-34.

8. Ashby M. F. Materials Selection in Mechanical Design. 2nd ed. Oxford, UK: Butterworth-Heinemann, 1999.

9. Gupta N. Material selection for thin-film solar cells using multiple attribute decision making approach. Mater Des. 2011. Vol. 32. P. 1667-71.

10. Reddy G. P., Gupta N. Material selection for microelectronic heat sinks: an application of the Ashby approach. Mater Des. 2010. Vol. 31. P. 113-17.

11. Palego C., Deng J., Peng Z., Halder S., Hwang J. C. M, Forehand D. I., Scarbrough D., Goldsmith C. L., Johnston I., Sampath S. K., Datta A. Robustness of RF MEMS capacitive switches with molybdenum membranes. IEEE Trans. Microw. Theory Tech. 2009. Vol. 57. P. 3262-69.
Navneet Gupta, Abhinav Mishra

DIELEKTRIKO MEDŽIAGOS HIBRIDINIAMS MIKROBANGINIAMS INTEGRINIAMS

\section{GRANDYNAMS PARINKIMAS}

Santrauka

Straipsnyje pateikiamas sisteminès analizès principo taikymas parenkant dielektriko medžiagą hibridiniams mikrobanginiams integriniams grandynams. Sisteminè analize šiam tikslui labai tinkama, nes grandynų projektuotojams tenka rinktis iš daugybès dielektrinių medžiagų, o kiekviena jų turi savo privalumų ir trūkumų. Taikomi du sprendimų prièmimo metodai. Pirmiausia naudojamas Ashby metodas, grindžiamas daugiatikslių sprendimų priemimo schema (angl. Multi-Objective Decision Making, MODM), o po to - pirmumo eilès pagal artimumą idealiam sprendimui metodas (angl. Technique for Order Preference by Similarity to Ideal Solution, TOPSIS) kaip daugiakriterinio sprendimų prièmimo metodas (angl. Multiple Attribute Decision Making, MADM). Taikymo rezultatai rodo, kad abu metodai vienas su kitu gerai dera ir yra tinkami medžiagų parinkimui, o tinkamiausia dielektrinè medžiaga hibridiniams mikrobanginiams integriniams grandynams yra safyras.

Raktažodžiai: medžiagos pasirinkimas, mikrobanginis integrinis grandynas, TOPSIS, Ashby metodas, MODM, MOADM 